\title{
Genesis 14 and "The Four Quarters"1
}

\author{
Alice Deken (University of The Free State)
}

\begin{abstract}
The first twelve verses of this episode describe an event which was representative of the relationship of the Assyrian Empire with vassal states. Four kings invade a rebel state, subdue it, and take hostages. These events reflect what the writer regards as the typical behaviour of kings both invaders and defenders, who reject the role of the priesthood and hence their subordination to God. These kings are opposed to, and compared to an alliance comprising the king of Sodom, Melchizedek who is both priest and king, and Abram who is not a king. The final member of this opposing foursome is God. This episode takes place within the ongoing debate both within the Bible and in the ANE on the relationship between palace and temple. This text itself becomes evidence for a reconfigured "four corners of the world" presided over by the God of Abram.
\end{abstract}

KEYWORDS: Genesis 14; four quarters; Melchizedek; Abram; Lot.

\section{A INTRODUCTION}

This semantic study is part of a larger project in which I expand the implications of the author's use of a term without immediately limiting meaning to its relevance to the story. I include both the biblical text and the literature of the ANE in my consideration of the implications of the language used. I do not make a judgement on the value of this enterprise in regard to individual passages before I begin. A passage comes to my attention and I analyse it and present my findings. Based on similar work that I have done on 2 Sam $21^{2}$ and Jer $36^{3}$ this method results in both the confirmation of conclusions reached by other critical methods, ${ }^{4}$ and also possible or alternative explanations for words and grammatical constructs which may have been regarded as errors. These "errors"

* Submitted: 27/09/2017; peer-reviewed: 01/11/2017; accepted: 01/03/2018. Alice Deken, "Genesis 14 and "The Four Quarters"," OTE 31 no. 1 (2018): 66-89. DOI: https://doi.org/10.17159/2312-3621/2018/v31n1a5

1 An earlier version of this paper was read by Dr Tarja Philip of the Hebrew University of Jerusalem.

2 Presented at a conference entitled "Rethinking Justice" hosted by the Department of Theology of the University of the Free State, South Africa, 24 August, 2015.

3 Alice Deken, "Does Prophecy Cause History? Jeremiah 36 - A Scroll Ablaze," OTE 30/3 (2017): 630-52.

4 Although I have avoided commenting on form here, there is significant synergy between the results of this semantic analysis and the conclusions reached by formcriticism and historical-criticism. 
are often textual and form-critical problems resulting from the presumed editorial process of combining different texts to form a whole. This semantic reading can justify the inclusion of form-critical and narrative difficulties on thematic grounds.

My reading suggests that the post-exilic writer/compiler/editor of this fragmentary text, is utilizing different aspects of an old Assyrian metaphor for hegemony, that of "the four quarters." His intention seems to be to backdate the episode to the period of Abram, in order to identify Abram and the entire history of the Promised Land with the rejection of kingship; the establishment of a priesthood subordinate to God; the boundaries of the Promised Land, and the extension of the God of Israel's domain to "the four quarters of the world."

\section{The Four Quarters}

The first reference by an Assyrian king to the "four quarters of the world" was by Naram Sin (2254-2218 BCE): "the mighty king of Agade, and of the four quarters." These "four quarters" are not a geographical representation of the area over which he ruled but represent something like "known world." Babylonian and Assyrian kings continued to use this image of power, derived from the four points of the compass throughout the period of their empires:

The geographic term "The Four Regions" is based on a tradition of dividing the earth's surface into northern, southern, eastern and western quadrants, derived from the four winds or compass point directions. ... passages in The Tukulti-Ninurta ${ }^{6}$ Epic (Machinist TN Epic 66 I AI:3', 116 I A V:17), where the terms kippat sar erbetti "circle of the four winds" and kippat erbetti "circle of the winds" refer to Tukulti-Ninurta's empire. ${ }^{7}$

The different regions were referred to as east, west, north and south, but the image of the compass-points was a metaphor for the very large, largely imaginary region of the king's all-powerful rule. The image of the "four quarters" and global hegemony, represented approval by the gods for the king. The "four quarters" in its' relationship to sovereignty as a metaphor for hegemony, and not as geography, was implicit in that "geography" from its' inception:

The presentation of lists of cosmic regions ... demonstrates that the beliefs expressed in the lists were part of both the general religious traditions of Mesopotamia and the tenets of Mesopotamian

5 Douglas Frayne, The Royal Inscriptions of Mesopotamia: Sargonic and Gutian Periods 2334-2113 BC (Toronto: University of Toronto Press, 1993), 88.

6 Tukulti-Ninurta (1243-1207 BCE).

7 Wayne Horowitz, Mesopotamian Cosmic Geography (Winona Lake: Eisenbrauns, 2011), 298. 
astronomy and astrology. Of course, the disciplines of astronomy and astrology were but part of the overall religious system. ${ }^{8}$

This figurative understanding of the metaphor was fundamentally affected in the Persian period when the metaphor became history with the appointment of four generals known by the compass points - general of the east, general of the west, general of the north and general of the south, and "a general who is above the four generals" 9 . This expansion of the metaphor from a horizontal, geographical entity to a vertical, temporal image for the succession of empires, had always been implicit in the representation of the "four quarters" by kings. The image with its' expanded metaphorical implications was in use throughout the biblical period.

In the Book of Daniel we find this vision of four kingdoms:

You, O king ... you are the head of gold. But another kingdom will arise after you, inferior to yours; then yet a third kingdom, of bronze, which will rule over the whole earth. But the fourth kingdom will be as strong as iron ... And in the time of those kings, the God of Heaven will establish a kingdom ... (Dan 2:37-44) ${ }^{10}$.

The expansion of the metaphorical implications of "four quarters" to include four "empires" is implicit in the association of the compass points and royal hegemony with claims to the land. By the time that the Book of Daniel came to be written, the overtaking of Assyria by Babylonia was already part of the mythical past. The Jewish and early Christian world saw the establishment of the Persian Empire in apocalyptic terms as evidence that the succession of empires implicit in the metaphor was unrolling: Assyria - Babylonia - Persia Greece $^{11}$, to be succeeded by a fifth and final empire. The association of the compass points and hegemony with the succession of empires as seen in Daniel could only occur when that perceived succession of empires had taken place and is necessarily a late augmentation of the metaphor.

\section{B CHAPTER 14}

The names of the four kings of Gen 14:1 and the terms of their association imply that they came from Mesopotamia generally. But the history of the Assyrian Empire was only relevant to Palestine:

8 Horowitz, Cosmic Geography, 8.

9 Daniel T Potts, "Once More on 'the general who is above the four generals' and his congeners," NABU 3 (2007): 51.

${ }^{10}$ All translations of the text are taken from Jewish Publication Society, JPS HebrewEnglish Tanakh, 2nd ed. (Philadelphia: The Jewish Publication Society, 1999).

${ }^{11}$ Chaldean - Medean - Persian - Greek? Depending on your point of view. 
... during the 9th to 6th centuries BCE ... the period during which Assyria and Babylonia cast their imperial shadow over the Near East and brought the kingdoms of Israel and Judah under their control. ${ }^{12}$

The Abram/Abraham-ic period of the bible is perhaps a millennium or more before Palestine fell under the Mesopotamian empires. While Gen 14 is placed in the Patriarchal period of "long ago," the principle of vassalage and the invasion as a consequence of rebellion described here, would refer to the period after $800 \mathrm{BC}$ when parts of Palestine were subject to or being fought over, by the Mesopotamian regions. Emerton identifies references to the Davidic period ${ }^{13}$ but he is referring specifically to the Melchizedek episode, and this does not reconcile the mishmash of periods that we find represented in the episode. The writer working at a much later date, is making use of a metaphor with ancient antecedents to establish the claim to the Promised Land as Abram-ic, and to impose a thematic unity over the three or more units that he was working with.

The episode progresses between successive representations of kingship beginning with the four Assyrian kings who represent a godless kingship described by the "four quarters" of the compass. Abram's victory is first acknowledged by the king of Sodom, a king of the "plain" (שוה) who subscribes only to kingship and not to God. He acknowledges Abram whose God is "on high" on his own terms. Abram is then greeted by Melchizedek who is both king and priest and who acknowledges Abram in the name of his God "most high." Abram having won his victory with his three allies and a handful of men, can only have done so under the auspices of his God. This representation of a victory without a king, demonstrates God's power and the concomitant feebleness of kings who are opposed by God. This positions this episode within the larger ANE debate about the relationship between the palace and the temple.

In the last verse of ch. 13 - the preceding chapter, we were told that Abram חבר Gen 13:18) "in Hebron," a name derived from the root בחברון "association, league" $" 14$ and related to the thematic number 4 by its other name:

The origin of the name is in dispute. It has been connected with the Hebrew stem h-b-r, "to unite," signifying a confederacy of four separate settlements; hence its other name, Kiriath-arba, "city of four," in Genesis 23:2 and 35:27. ${ }^{15}$

12 Mordechai Cogan, The Raging Torrent (Jerusalem: CARTA, 2008), x.

13 “... no period would have been as appropriate as that of David." See John A. Emerton, "The Riddle of Genesis XIV," VT 21/4 (1971): 426.

14 BDB, 289a.

15 Nahum M. Sarna, Genesis, JPSTC (Philadelphia: The Jewish Publication Society, 1989), 101. 
Abram is called upon to instigate an "alliance": והם בעלי ברית אברם "these being Abram's allies" (Gen 14:13), in order to rescue Lot, who has been taken captive by the invader kings.

The term ברית invokes the covenantal relationship with God:

$$
\begin{aligned}
& \text { ביום ההוא כרת יהוה את-אברם ברית לאמר לזרעך נתתי את-הארץ הזאת } \\
& \text { מנהר מצרים עד-הנהר הגדל נהר-פרת ארת ברת לאית }
\end{aligned}
$$

On that day the LORD made a covenant with Abram, saying, "To your offspring I assign this land, from the river of Egypt to the great river, the river Euphrates" (Gen 15:18).

The term ברית is here used in opposition to the representation of the four kings, and their חברו with their opponents in v. 3. This episode seems to be moving from the ambiguous term חבר in to contrasting implications of relation to Abram - positioning Abram as the bearer of the covenantal relationship with God - a consequence of his rejection of kingship in favour of God.

The episode establishes Abram's claim to the boundaries of the Promised Land while claiming hegemony for his God over the "four quarters of the world" by Abram's defeat of the foreign kings and his alliance with Melchizedek ("my king is righteous"), king of Salem ("peace," Jerusalem). Abram's claim to the land, is represented by the physical space that the episode traverses representing both the limits of the Promised Land and the extent of the hegemony of the God of Israel. The divine implications of this physical aggrandizement of the Promised Land by both Abram and his God, is represented by the four kings who invade the land, and whose defeat can be seen as a claim of the God of Israel to the universal hegemony over "the four quarters" of the world that the invaders represented.

The story opens with the invasion of the Dead Sea region by an alliance of four foreign kings. The opposing kings are defeated and Lot, Abram's kinsman, is rounded-up as part of the booty.

\section{Genesis 14:16}

$$
\text { ויהי בימי אמרפל מלך-שנער אריוך מלך אלסר כדרלעמר מלך עילם ותדעל }
$$

Now, when King Amraphel of Shinar, King Arioch of Ellasar, King Chedorlaomer of Elam, and King Tidal of Goiim (Gen 14:1).

16 I comment on verses individually even though as here, sentences may run across more than one verse. My emphasis is on the thematic unity of the episode as a whole. 
Appropriately, the pericope opens with an Akkad-ism representing the incursion of the foreign kings into the land of Israel, literarily and historically represented by its' syntactic encroachment over the dating of the incident:

Heb. $\operatorname{bym}(y)$ stood here not for the construct form "in the day(s) of," but as a rendition of the cognate Akkadian conjunction e/inuma/i "when," originally "in the days, at the time"; the final $-y$ would not have appeared in early consonantal writing. ${ }^{17}$

The names of these four kings has not been correlated with four kings who could plausibly have been united in a historical sortie of the kind described here. On the other hand there is some evidence for them being actual names, chosen to suggest that the episode is historical:

... it is now well known that Arioch and Tidal resemble names that are attested elsewhere in the Ancient Near East, and that Chedorlaomer can be plausibly explained as compounded of two elements that are found in Elamite names ... ${ }^{18}$

The Akkadian word for the leading king כדר-לעמר is "kaddaru" meaning "to rear up" or "kadru" - "warlike."19 ל-עמר refers to "to Gomorrah." Thus the name of the Elamite king is "warlike to Gomorrah" suggesting that the king was named for his relationship to the story line and not to history. Astour adds the implication that Gomorrah's name represents its culpability in the crimes that it suffers for:

Gomorrah (עמרה) has a fitting etymology: Hebrew התעמר (hithpa 'el), "to deal violently, tyrannically," Arabic gamara, "to feel hostility." 20

Although the narrative ostensibly takes place before the destruction of Sodom and Gomorrah, their history has been integrated into the imagery of the story.

The מלך is used four times in the first verse and five times in the second, as the names of the contending and opposing kings are itemized. There are over 5000 occurrences of the root in the HB, an average of just over five occurrences per chapter. Though this suggests that "sovereignty" and "kingship" are a theme in the Bible, these two verses represent nearly double the average per chapter for the bible as a whole. This is compounded by the fact that the root

17 Ephraim A. Speiser, Genesis, AYB (New Haven: Yale University Press, 1964), 101.

18 Emerton, "Riddle," 435-36.

19 HALOT, 461.

20 Michael C. Astour, "Political and Cosmic Symbolism in Genesis 14 and its Babylonian Sources," in Biblical Motifs: Origins and Transformations, ed. Alexander Altmann (Cambridge: Harvard University Press, 1966), 72. 
continues in use throughout the chapter: “... The word 'king' appears in the chapter twenty-eight times."21

These four kings who represent four ancient empires are all defeated by Abram and his God. The first שנער is an ancient name for Babylon, the second עלסר is king of what may be Ashur, the third עילם is more certainly king of Elam and the fourth גוים is king of some undefined area which may or may not be Hatti or Syria/Palestine. But if the principle is correct, then we can use any western region to give us a Mesopotamian representation of the geographical "four quarters of the world":

Under Naram-Sin the grandson of Sargon, the ideology for territorial rulership was enlarged in a number of ways: The king's name was written with the semantic classifier "divinity" and so the king was portrayed not just as a highly competent mortal ruler but one who exercised the right to rule because he was more than human. Moreover the ruler took a new title as "King of the Four Quarters," that is, of everywhere, not just from a victorious city-state. ${ }^{22}$

The title is flexible in terms of whom/what it represents, ${ }^{23}$ and to have remained relevant over an extended historical period it must have been possible to adapt it to a variety of historical circumstances, as is here represented.

The suggestion, that the sources of ch. 14 are found in the literature of the ANE, is of course true for much of the Tanak, but has a more specific connotation here, ${ }^{24}$ in that vv. $1-11$ seem to be modelled on an Assyrian summary text:

What it describes is a typical situation of the period between the eighth and the sixth centuries, many times experienced by Israel and Judah and occurring with distressing regularity in the Assyrian royal inscriptions: a king is forced to recognize Assyrian overlordship, and promises to pay a heavy tribute imposed upon him. A few years later he stops paying tribute, and seeks help from other rebel vassals or outside powers. Then, usually the very next year, an Assyrian punitive expedition, often led by the king, invades the country,

21 Bruce K. Waltke and Cathi J. Fredricks, Genesis: A Commentary (Grand Rapids: Zondervan, 2001), 226.

22 Norman Yoffee, "Political Economy in Early Mesopotamian States," ARA 24 (1995): 293.

23 Touraj Daryaee, Sahrestaniha I Eransahr: A Middle Persian Text on Late Antique Geography, Epic and History (Costa Mesa, CA: Mazda Publishers Inc, 2002), 8; Joseph W. Swain, "The Theory of the Four Monarchies Opposition History under the Roman Empire," CP 35/1 (1940): 1, 2, 3, 7.

24 Speiser, Genesis, 17 after Albright posits the Spartoli tablets as a source. 
devastates it, subdues it again, and carries off to Assyria all movable goods and a large number of people. ${ }^{25}$

A summary inscription of Tiglath-Pileser III (745-727 BCE) seems to reflect this kind of event and includes some imagery that also occurs in Gen 14:

[Palace of Tiglath-pileser (III), great king, mighty king, king of the world, king of Assyria, king of Bab]ylon, king of Sumer and Akkad, king of the four quarters (of the world); [valiant man who, with the help of (the god) Assur, his Lord], smashed [like pots all who were unsubmissive to him], swept over (them) like the Deluge, (and) considered (them) as (mere) ghosts; [the king who marched about at the command of the gods Assur, Samas, and Marduk, the great gods, and] exercised authority over lands [from the Bitter] Sea of BitYakin, as far as Mount Bikni in the east, [up to the Sea of the Setting Sun, as far as Egypt, from the horizon to the zen]ith, and exercised kingship over them (Summary Inscription 12). ${ }^{26}$

Some points of coincidence between this summary text and Gen 14 are:

(i) This chapter demonstrates an instance of the process by which a party of Mesopotamian kings mounts an offensive against a territory or vassalstate which has rebelled.

(ii) Flood imagery, is overt in the Assyrian text but there are implied references to "flood" in ch. 14 - הפך, אמרפל. The implications of the flood imagery are different in the two traditions: The biblical story of the Flood understands the flood as a punishment for wrongdoing on the part of mankind. The Assyrian text regards flood as a symbol of sovereign power, manifested by the flooding of Babylon by Sennacherib in 689 BCE. These traditions collide when these kings representing all the powers on earth arrive as a scourge against the five kings of the plain.

(iii) In lieu of the large-scale relocation of peoples especially typical of Assyrian hegemony, Lot is taken captive. Perhaps on account of Lot's attack on the principle of חבר in the previous chapter (Abram remains in חברון alone).

(iv) Sarna suggests that the reference to the רפאים (v. 5) includes the meaning "shades of the dead"27 ("ghosts"), represented by the "powerlessness" of the enemy, in our Assyrian source.

25 Astour, "Cosmic Symbolism," 70.

26 Hayim Tadmor and Shigeo Yamada, The Royal Inscriptions of Tiglath-Pileser III (744-727 BC), and Shalmaneser V (726-722 BC), Kings of Assyria (Winona Lake, IN: Eisenbrauns, 2011), 138.

27 Sarna, "Genesis," 105. 
(v) The conventional invocation of gods in the Assyrian text ("Ashur, Shamash and Marduk"), may correlate in our text, with the conversation between Abram and Melchizedek over the definition of אל עליון, and in the chapter as a whole between the "high" God of Abram and Melchizedek, and the gods of the other kings of the "valley."

In these terms, the claim for one or more underlying cuneiform source, seems justified. This does include the implication that the text draws on the period during which parts/all of Palestine were subject to the Assyrian Empire. The reading that I present here, supports $\mathrm{Na}^{\text {'amans }}{ }^{28}$ dating of the text to the Persian period. This semantic reading rather describes the process by which the events in this episode have been edited so that they appear to have taken place in the time of the patriarchs. This, it seems to me, is the purpose of structuring the text around the ancient, but still current, image of "the four quarters."

The story ostensibly concerns the incursion of four allied kings into Palestine on grounds of rebellion מרדו (v. 2) which inevitably implies that a vassal has reneged on his taxes. The name the first king is מרפל (v. 1):

... the "Chedorlaomer texts" clearly point to Marduk-apal-iddina as the prototype of Amraphel. One of the numerous ideograms for the name of Marduk was written ... 'A.MA.RU, which signifies "deluge."29

The four kings of v. 1 represent one aspect of the kingship theme as it is examined in this text. The implication of this verse is that the Assyrian kings act independently of religious rule. This view is not borne out by the Assyrian text cited here, but rather reflects the view of the writer and presumably the Israelite priesthood who rejected kingship altogether in favour of priestly mediation between their God and his subjects. The relation between church and state was a matter of conflict and negotiation throughout the lands and the period of the ANE. There is no direct reference to any god verse 1 . The idiosyncratic spelling for Ashur אלסר may be in part to avoid invoking the god אשור. This is in keeping with the express attitude of the biblical prophets, that earthly kings displace the role of God (1 Sam 8:7).

\section{$2 \quad$ Genesis 14:2}

$$
\begin{aligned}
& \text { עשו מלחמה את-ברע מלך סדם ואת-ברשע מלך עמרה שנאב מלך אדמה } \\
& \text { ושמאבר מלך (צביים/צבויים) ומלך בלע היא-צער: סדים ואל על על }
\end{aligned}
$$

\footnotetext{
28 Nadav Na'aman, “Abraham's Victory over the Kings of the Four Quadrants in Light of Darius I's Bisitum Inscription," Tel Aviv 42 (2015): 72-88.

29 Astour, "Cosmic Symbolism," 99.
} 
made war on King Bera of Sodom, King Birsha of Gomorrah, King Shinab of Admah, King Shemeber of Zeboiim, and the king of Bela, which is Zoar (Gen 14:2).

The king of Sodom's name ברע - "in evil," is also an anagram for - "fire, burning" - appropriately pre-figuring the disaster that will befall Sodom. The destruction of Sodom and Gomorrah are prefigured in this verse. Sodom by its king whose name is ברע - "in evil," and Gomorrah, associated with violence and tyranny in its' own name, and violent overthrow through the name of the conquering king Chedorlaomer. Gomorrah with the other four cities of the plain has defied those four kings who represent the existing world order, in the opening verse of this chapter.

Testifying to the difficulties implied by this text, Sarna comments on the absence of a name for the king of Bela:

The absence of a name for the king of Bela (v.2), in contrast to the other four local monarchs, reinforces the conjecture that behind the biblical account is an independent source, which must no longer have preserved the information. Scripture faithfully adhered to that source; otherwise, the Narrator would surely not have been at a loss to invent a name for him. ${ }^{30}$

I would disagree with Sarna, although the suggestion was already mooted by Skinner ${ }^{31}$ and has also been quoted by von Rad, to argue that, as the king in question could be assigned to Bela (בלע), "swallow up, engulf, confuse, confound," 32 the writer did not need any additional information. The destruction and annihilation, or "swallowing up" that represented, met the requirements of the writer. It is anyway, quite absurd to suggest that the names of an array of kings meaning "in evil" (ברע), "in wickedness" (ברשע), "[who] hates his father" (שנאב), "[the] Name is lost" (שמאבר) and "swallow-up/engulf" (בלע) (ברע) (all of v. 2) - is based on fact. The word represents the resulting confusion from the subversion of language that we see here. The literal values of the text undermine the supposed historical narrative. The kings' names are presented as historical, but actually represent only their meaning in the text. The writer is using the genre of "history-writing," while adducing "facts" that meet his literary needs. The bible itself comments on the capacity of the word בלע to undermine the ostensible meaning of the text ${ }^{34}$ :

30 Sarna, "Genesis," 102.

31 John Skinner, A Critical and Exegetical Commentary on Genesis, ICC (New York: Charles Scribner's Sons, 1910), 259.

32 BDB, 118.

33 Sarna, Genesis, 104.

${ }^{34}$ Elsewhere Bela is the name of a king: Bela son of Beor reigned in Edom, and the name of his city was Dinhabah (Gen 36:32). 


\section{בלע אדני פלג לשונם כי-ראיתי חמס וריב בעיר:}

O LORD, confound their speech, confuse it! For I see lawlessness and strife in the city (Ps 55:10).

The writer invokes war, fire and flood from the Mesopotamian kings against the kings living in the land that God has promised to Abram. ${ }^{35}$

Naturally for the ironies which this text is already generating, this same king who either lacks a name or a city, is associated with צער "insignificance," 36 and he is not referred to directly again in this chapter. Although the omission of the name of the king or the name of his city, may simply reflect some confusion over which it was, that he allowed the omission to stand represents a literary value and does not shore up the argument for the historicity of a text which is not historical. Further, as we already saw with the name בעל is also an anagram for. We know who he worships.

The king of ברע in "in evil." The writer does use Sodom's bad reputation in order to anachronistically adduce a historical fact. ברשע is king of עמרה , explicitly linking these kings, already associated by the theme of kingship and the ruling metaphor in this periscope, to the invader kings, led by כדרל-עמר.

שנאב who "hates his father (in heaven: Rashi)" is king of the "ground" אדמה. In this one careless allusion to a man who "hates his Father," God's creation of the earth, is invoked and despised. This is obviously a situation which cannot be allowed to persist. The invader kings and the kings of the valley where Lot has made his home, are associated by their godlessness. In the battle between church and state, they believe that they have won. They are שמ-אבר, they have "lost His name."

The concatenation of disastrous references implicit in the names of the kings of their own cities of the plain, implies that it is not the foreign kings who are bringing the disaster to the cities of the plain. The foreign kings are simply agents of destruction. The concomitant of their agency, is that they are acting under the auspices of the God of Israel. Their actions are part of his plan. The raw imagery of v. 2 of this episode describes the nature of kingship as the Israelite priesthood would have it understood, represented by Mesopotamian hegemony over the land of Israel, and flood as a scourge for its people.

35 The kings of the cities of the plain have so completely displaced God's rule that there is even a fifth king among them. The writer demonstrates what an earthly representation of the "five empires" - a satire on the succession of four empires followed by the establishment of God's empire on earth, would look like, by showing us these five kings. That God would represent the fifth empire is fundamental to the metaphor as it is used in the HB.

36 BDB, 858. 


\section{Genesis 14:3}

$$
\text { כל-אלה חברו אל-עמק השדים הוא ים המלח: }
$$

All the latter joined forces at the valley of Siddim, now the Dead Sea (Gen 14:3).

This godless coterie of earthly kings are "joined together" חברו - חברו for battle, in the same root as that used to tell us that Abram dwelt בחברון, entailing Abram's involvement in the events that are about to occur. At the same time this use of the same root is ironic, in that for Abram his home is a place where he has allies that he can call on in terms that evoke his covenant with God בעלי ברית. The antagonists gather in a "valley" - עמק השדים, ("heights") being reserved for Abram and his God. These three here are the only occurrences of the name of the valley in the $\mathrm{HB},{ }^{38}$ and translates as "demon-valley." 39

All this information in this verse is followed by a narratorial aside concerning the הוא ים המלח :עמק השדים. This ironic comment is fundamental to the text. The land that nine kings are prepared to go to battle over is the salt, instead of the water, of the sea - a representation of a greedy, grasping kingship that will grab any land at all costs.

\section{Genesis 14:4}

\section{שתים עשרה שנה עבדו את-כדרלעמר ושלש-עשרה שנה מרדו:}

Twelve years they served Chedorlaomer, and in the thirteenth year they rebelled (Gen 14:4).

The effect of the hinged, parallel structure of this verse, is to make Chedorlaomer the object of both clauses. Service is required and the consequences of rebellion are unavoidable. The inevitability that is suggested by this use of parallelism is that the invader kings from the "four quarters of the world" are acting in accordance with God's will. The biblical narrative both here and in the surrounding chapters is step by step laying out the extent of the Promised Land for Abram, matched by an increasing conception of the extent of God's hegemony. God appears to be managing events on a much larger scale than just what is understood as the Promised Land, and is seen here operating in relation to a plan which has taken fourteen years to come to fruition. The numerical parallelism represented here by " $\mathrm{x} / / \mathrm{x}+1$, , 40 supports both the sense of impending doom, and an increase in territory for Abram - and his God. The specific

37 BDB, 287.

38 Abraham Even-Shoshan, A New Concordance of the Bible, 7th ed. (Israel: The New Book, 2000), 1116 mentions עין עמק השדים ('there is no Demon-Valley').

39 BDB, 961.

40 Adele Berlin, The Dynamics of Biblical Parallelism (Bloomington: Indiana University Press, 1985), 71. 
invocation of this meaning of the noun שנה which is repeated iteratively within a parallel structure is summed up by Malachi:

\section{כי אני יהוה לא שניתי ואתם בני-יעקקב לא כליתם:}

For I the LORD do not change; therefore you, O children of Jacob, have not perished (Mal 3:6).

The play on שנה in V. 4, representing both "year" and "change," encapsulates the antitheses represented by the valley, a world ruled by earthly kings instead of by God. The cycle of years representing unpredictability and instability in this text, are opposed to a relationship with a "high," eternal, unchanging God.

The antithetic parallelism represented by מרדו and עבדו, result in almost the same conclusion as the synonymous parallelism of עבדו מרדו is used here to represent "service," (taxes) to the imperial overlord, represented in this text by Chedorlaomer, because the name is appropriate to the circumstance. The book of Kings testifies to the use of the root עבד to represent "service" as an act of worship. This is confirmed by the prophetic opposition to vassalage to foreign kings, which the prophets saw as an act of religious service to foreign gods:

$$
\text { וילך בכל-הדרך אשר-הלך אביו ויעבד את-הגללים אר עבד אביו וישתחו }
$$

$$
\text { להם: }
$$

He walked in all the ways of his father, worshiping the fetishes which his father had worshiped and bowing down to them (2 Kgs 21:21).

In the context, "service" and "rebellion" are associated with שנה, invoking "change" and "year," unstable and temporary in opposition to Abram's God. At the same time, this verse tells us that the kings "served" Chedorlaomer for "twelve" years, which also invokes "year" - a word used twice in this verse. As a result, the twelve years of service to Chedorlaomer are associated with the annual cycle of seasonal instability and "change" that is implicit in the use of שנה Tבד That the verb עב occurs in parallel, entails the corresponding term, the root מרד. The antithetic parallelism of these two terms in this text forces "service" and "rebellion" into a coercive relationship with each other. They are the inevitable consequence of kingship. The religious implications of the "service" include the suggestion that the "rebellion" is against the gods that they are "serving." The ironic aside referring to the "the Salt Sea," represents the annihilation of everything living in the face of a people who "hate their Father" and have "lost His name."

\section{Genesis 14:5}

ובארבע עשרה שנה בא כדרלעמר והמלכים אשר אתו ויכו את- רפאים

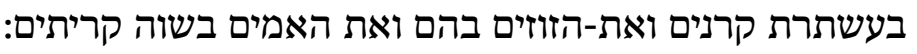


In the fourteenth year Chedorlaomer and the kings who were with him came and defeated the Rephaim at Ashteroth-karnaim, the Zuzim at Ham, the Emim at Shaveh-kiriathaim (Gen 14:5).

Just as in the previous verse, it proved opportune for this "historian" that the kings rebelled after exactly twelve years - in the thirteenth year, so that Chedorlaomer's expedition in pursuit of the rebellious kings comes in the fourteenth year. The Narrator has again the opportunity to emphasize the number "four" the implications of which are the subject of this chapter.

The root עשר here used to denote the "ten" in "fourteen" acquires a particular nuance in the sense of "tithe" in v. 20. But we have already said that non-payment of the tithe may have been the form of "rebellion" that brought the invader kings into the region. Hence עשר connects this part of the episode to the payment of the מעשר to Melchizedek in another part of the chapter. The payment of the tithe, implicitly becomes one of the mechanisms by which Abram instates a new moral order.

The narrator enumerates the deeds of the cities that are overthrown by the invader kings in terms of their names which has the effect of presenting the invasion as a necessary scourge. The רפאים are "translated" as "shades of the dead." הזוזים May refer to "murmurers," a suggestion of the "murmuring" of the "shades" amongst themselves. ${ }^{42}$ The ${ }^{44 " . a r e ~ " f r i g h t f u l ~}{ }^{43}$ "מימים"

These "frightful" people are found at שוה which is referred to again in the episode concerning the successive meetings first with the king of Sodom and then between Abram and Melchizedek. At this point in the narrative it iterates the point that has already been made. That these people, marked for destruction by their names, live on the שוה - "level"45 plains in contrast to the God of Abram who is "on high."

\section{Genesis 14:946}

את כדרלעמר מלך עילם ותדעל מלך גוים ואמרפל מלך שנער ואריוך מלך אלסר ארבעה מלכים את-החמשה:

\footnotetext{
41 Sarna, Genesis, 105.

42 Skinner, Genesis, 264. "Rephaim is the name for shades or ghosts; Emim probably means 'terrible ones'; and Zamzumim ... 'murmurers.' Schwally (Leben nach d. Tode ...) has shown that all three names originally denoted spirits of the dead."

43 Deuteronomy 2:10. It was formerly inhabited by the Emim, a people great and numerous, and as tall as the Anakites.

44 Sarna, Genesis, 105.

45 Sarna, Genesis, 105.

46 Due to space constraints I am unable to represent the entire chapter here.
} 
King Chedorlaomer of Elam, King Tidal of Goiim, King Amraphel of Shinar, and King Arioch of Ellasar - four kings against those five (Gen 14:9).

Several chapters after the episode recounted here, we find that Sarah was buried in Hebron at a time when it was still known by its original name, Kiriatharba.

ותמת שרה בקר'ת ארבע הוא חברון בארץ כנען ויבא אברהם לספד לשרה

ולבכתה:

Sarah died in Kiriath-arba - now Hebron - in the land of Canaan; and

Abraham proceeded to mourn for Sarah and to bewail her (Gen 23:2).

This suggests that Hebron would have been called קרית ארבע at the time when the events described here ostensibly took place. The writer chose to include the later reference to Hebron and חבר, at the beginning of this episode in which all kinds of alliances were being forged. In v. 9 the narrator compares the invading kings with the defence: "four kings against these five." The " $x+1$ " parallelism of v. 4 is embodied here in the defeat of five kings by four. The inadequacy of piling up kings in order to solve a problem is mocked here in preparation for Abram's defeat of the four invaders with his own alliance of four. חברו Abram with his three, Mamre, Eshkol and Aner acts in relation to his God ${ }^{47}$ and overcomes these conquering kings, representing God's ascendancy over all the events in this pericope.

The opposing foursome comprising Mamre, Eshkol, Aner, Abram and their men defeat the invader kings and Abram returns to the valley with the booty to establish the significance of what has occurred. Abram is met by the king of Sodom.

\section{$7 \quad$ Genesis 14:17-18}

ויצא מלך-סדם לקראתו אחרי שובו מהכות את-כדרלעמר ואת-המלכים אשר

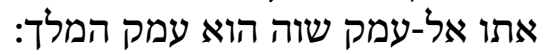

When he returned from defeating Chedorlaomer and the kings with him, the king of Sodom came out to meet him in the Valley of Shaveh, which is the Valley of the King (Gen 14:17).

In v. 17 the king of Sodom "comes out" to meet Abram after his successful pursuit of the invaders:

Hebrew yatsa' likr'at is a neutral phrase deriving its coloration from the context. It may mean "to greet," as in Exodus 4:14. I Samuel 18:6,

47 Genesis 14:22 "I swear to the Lord, God Most High, Creator of Heaven and earth." 
and Proverbs 7:15, or, much more frequently, "to confront," as in Numbers 20:20, 31:13, and Joshua 8:5.8

The decision to allow Sodom to make the diplomatic approach to Abram was presumably etiologically derived (as is ch. 19) from the fact of Sodom's destruction and the flooding of עמק השדים by the Dead Sea:

In all the passages of the Bible which mention the destruction of Sodom and Gomorrah, the term used is the verb הפך, "to overturn, to overthrow"; but in Akkadian, too, the verb sapanu, "to overthrow," is used to describe the effect of the deluge $(a b u b u){ }^{49}$

The king of Sodom figure represents both drought and flood which Sodom is particularly identified with here, through the name of the king and the events of the chapter, and also elsewhere in the HB (ch. 19). Additionally, the decision may have been based on the reference to the עמק השדים in 14:3, defined as "prop. Demon-valley," 50 invoking the wickedness of Sodom that has already been hinted at in v. 2 when the king was named ברע - "in evil" (and "fire"). The association of Sodom and Gomorrah with wickedness and destruction is attested to in the wordplay where שדם accur in the same text in a context of "poison" and "bitterness." The proverbial "wickedness" of סדם can be deduced from its association with שדם, which is derived from שדד - "harrow," "מדם used metaphorically in Jer 4:20 as the consequence of "disaster":

$$
\text { שבר על-שבר נקרא כי שדדה כל-הארץ :-10. }
$$

Disaster overtakes disaster, For all the land has been ravaged ... (Jer 4:20).

Placing the incident in Sodom ties the incident in with the sequence of events in the Book of Genesis as a whole, occurring as they do, immediately after the separation of Abram to Mamre, and Lot to Sodom, in Gen 13, but before the destruction of Sodom and Gomorrah in Gen 19.

The name Melchizedek occurs only twice in the HB, here in v. 18 and in Ps 110:4:

$$
\text { נשבע יהוה ולא ינחם אתה-כהן לעולם על-דברתי מלכי-צדק }
$$

The LORD has sworn and will not relent, "You are a priest forever, a rightful king by My decree" (Ps 110:4).

\footnotetext{
48 Sarna, Genesis, 109.

49 Astour, "Cosmic Symbolism," 103.

50 BDB, 961.

51 BDB, 961.
} 
Similarly, the reference here in v. 18 is to a "just, legitimate" king, derived from the Mesopotamian background of the events depicted here:

The Canaanite counterpart of Akk. Sarru (m) ken "Sargon," literally "the king is just, legitimate," 52

and (perhaps) from its standing here, in opposition to the king of Sodom (ברע).

The king of Sodom meets Abram in the verb קרא as opposed to the more typical verb קרב. But קרא can have an antagonistic connotation, which is made explicit in 1 Sam 4.1:

$$
\text { ויהי דבר-שמואל לכל-ישראל ויצא ישראל לקראת פלשתים ללחמה }
$$

And Samuel's word went forth to all Israel. Israel marched out to engage the Philistines in battle ... (1 Sam 4:1).

In one verse Isaiah references three of the aspects of the destruction of Sodom and Gomorrah that are invoked in relation to the meeting between Abram and Melchizedek:

והיתה בבל צבי ממלכות תפרת גאון כשדים כמהפכת אלהים את-סדם ואת-

עמרה:

And Babylon, glory of kingdoms, Proud splendor of the Chaldeans, Shall become like Sodom and Gomorrah Overturned by God (Isa 13:19).

Babylon, which was destroyed by Sennacherib in 689 BCE by flooding, is being overtly compared to the destruction of Sodom and Gomorrah, and the verb used is הפך. While drawing on the eschatological implications of their names, the writer is also drawing on the proverbial destruction of Sodom and Gomorrah for infamy, before the destruction has actually taken place (in ch. 19):

It shall be as when God overthrew Sodom and Gomorrah and their neighbors - declares the LORD; no man shall live there, no human shall sojourn there (Jer 50:40).

This is consistent with this writer's position in relation to historical data, which subordinates everything to the needs of his narrative, which is concerned to define the difference between serving a king and serving God.

The encounter between Abram and Melchizedek takes place in the valley. Melchizedek refers to his own God as אל עליון. In context this includes a generic reference to a "high" God implicitly referencing Abram's God, who is regularly

52 Speiser, Genesis, 104. 
associated with the same epithet and is contrasted with the "valley" of Sodom and Gomorrah.

The name of the valley is ${ }^{53}$ - "even out, level off"54 in this text, it echoes the reference to low-lying ground which is implied by עמק. The suggestion is that the text is not merely trying to describe a location, which would be something like "the valley of the plain." The root also means "to become the same, to be equal with," דומה

\section{ואל-מי תדמיוני ואשוה יאמר קדוש:}

To whom, then, can you liken Me, To whom can I be compared? says the Holy One (Isa 40:25).

But it also "corresponds to Akk. (Mari) sawum something like "wasteland." 56 We also have here what is according to Smith, a later interpolation ${ }^{57}$, in that another name has been added to locate the old name: הוא עמק המלך (Gen 14:17):

The explanation "that is, the King's Valley" seems to be a gloss by an editor who had in mind the King's Valley mentioned in II Sam 18:18 a place which was probably near Jerusalem. ${ }^{58}$

But the new name (not the same place, by the way) describes the "valley" as being of the "king." The kings are identified with a valley, which is called "equal with," suggesting a reduction of rank to the level of the valley. The association with "wasteland" in Akkadian; the destruction of Sodom and Gomorrah, both cities of the "plain"; one of the Kings, Gomorrah, implied in the name of כדר-ל-עמר; and the devastation of the two cities are all prefigured in these echoes. At the same time, not only does the use of these terms pre-figure the destruction of Sodom and Gomorrah, but it is on account of the destruction of Sodom and Gomorrah that these terms have acquired their pejorative overtones. The gloss on עמק המלך עמ is deeply ironic in this context. The kings in this chapter (and there are lots of them), both the invader kings and the local kings, are being "levelled" and "compared" in the valley, in relation to Abram, who is never called "king," and whose God is associated with עלה - high.

Only now, when the other kings mentioned in this episode have been identified with the level plain, a wasteland and the destruction of Sodom and

53 Even-Shoshan, Concordance, 898. The word is used five times in this chapter but only 67 times in the Tanak.

54 HALOT, 1437.

55 HALOT, 1436.

56 HALOT, 1438.

${ }^{57}$ According to myself it could easily be part of the original text, but written much later than Smith envisages.

58 R. H. Smith, “Abram and Melchizedek (Gen 14.18-20)," ZAW 77 (1965): 140. 
Gomorrah, does Melchizedek "my king is righteous" appear. He appears in the same verb יצא as did the king of Sodom.

\section{Abram is met by Melchizedek}

$$
\text { ומלכי-צדק מלך שלם הוציא לחם וייו והוא כהן לאל עליון: }
$$

And King Melchizedek of Salem brought out bread and wine; he was a priest of God Most High (Gen 14:18).

But the verb has been augmented by the hip 'il enabling the king to "bring" bread and wine to Abram, as opposed to the implied antagonism with which the king of Sodom "met" Abram. But לחם is the verbal root of "fight, do battle."59

Melchizedek is also king of שלם "peace". It seems unnecessary to introduce the additional implications of a possible reference to Jerusalem to explain the occurrence of this root here:

The simplest solution is to treat שלם as an adjective describing Melchizedek. ${ }^{60}$

In the occurrence of the root in ch. 34 of Genesis, the root refers to a covenantal relationship between the Abrahamic family group and the people of Shechem. Smith suggests, referring to the use of the root שלם in ch. 34:

Here שלם alludes to a covenant relationship, and hence may be taken to mean "in a state of covenant-peace."

Finally here, we have an exemplary alliance in which Melchizedek, first a priest and then a king, is allied to Abram who derives his rank from his alliance with God, which places him "on high" with Melchizedek.

\section{$8 \quad$ Verse 19}

\section{ויברכהו ויאמר ברוך אברם לאל עליון קנה שמים וארץ:}

He blessed him, saying, "Blessed be Abram of God Most High, Creator of heaven and earth" (Gen 14:19).

As king of שלם Melchizedek brings Abram bread and wine in recognition of the alliance. As the "priest of God Most High," Melchizedek "blesses" Abram. The correlative for the references to kings, valleys and plains in relation to Abram, is in relation to "God Most High." The name of the God seen only in its constituent terms - a "high" God, suggests that אל עליון is being used by Melchizedek as the

\footnotetext{
59 BDB, 535.

60 Smith, "Abram and Melchizedek," 142.

61 Smith, "Abram and Melchizedek," 143. See Exod 32:6.
} 
name of his god, and by Abram as a description of his. In recognition of the differences between them, Melchizedek, a "righteous" king, selects a name that represents the distinction between their God, the God of Abram and of Melchizedek, and that of the king of Sodom.

Habel supports this (slight) de-sacralisation of the references to a god in these verses:

El, moreover, assumes a diversity of epithets which may stem from a variety of ancient sources. Thus we meet the names El Shaddai, El Bethel, and El Olam, formulations which are similar to the designation of El Elyon, and which suggest the adoption of Elyon as a titular ascription rather than an independent name. ${ }^{62}$

Finally Brueggemann is able to link these references to God to the historical references of the chapter, specifically the references to the kings from the "four quarters" of the world in v. 1:

The formula "Most High God" ... is used in contexts in which the sweep of faith goes beyond the history of Israel to make universal claims for this God. ${ }^{63}$

The verb קנה means both "to acquire, buy," and "to create, produce"64.

$$
\begin{aligned}
& \text { והשיבך יהוה מצרים באניות בדרך אשר אמרתי לך לא-תסיף עוד לראין לראתה } \\
& \text { והתמכרתם שם לאיביך לעבדים ולשפחות ואיר ואין קנה: }
\end{aligned}
$$

The LORD will send you back to Egypt in galleys, by a route which I told you you should not see again. There you shall offer yourselves for sale to your enemies as male and female slaves, but none will buy (Deut 28:68).

ה-ליהוה תגמלו-זאת עם נבל ולא חכם הלוא-הוא אביך קנה הוא עשך ויכננך:

Do you thus requite the LORD, $\mathrm{O}$ dull and witless people? Is not $\mathrm{He}$ the Father who created you, Fashioned you and made you endure! (Deut 32:6).

Gammie raises the question: why was קנה used instead of ברא?

Had the interpolation been a post-exilic formulation, one would have expected that bore more naturally would have been used. ${ }^{65}$

62 Norman C. Habel, "Yahweh, Maker of Heaven and Earth: A Study in Tradition Criticism," JBL 91/3 (1972): 322-23.

63 Walter Brueggemann, Genesis, IBC (Atlanta: John Knox Press, 1982), 135-36.

64 HALOT, 1111-12.

65 John G. Gammie, "Loci of the Melchizedek Tradition of Genesis 14:18-20," JBL 90/4 (1971): 386. 
The reason suggested by the text is that קנה carries the additional implication of "acquisition" or "purchase." At the same time, as Melchizedek is cementing the ties between himself and Abram, he is referring to the military alliance between them by offering the לחם and implying a relationship of reciprocal obligation in his choice of the verb that he uses to refer to his god. Also, קנה here used in the sense of "creator," carries an overtone of redemption:

$$
\text { זכר עדתך קנית קדם גאלת שבט נחלתך הר-ציון זה שכנת בו: }
$$

Remember the community You made Yours long ago, Your very own tribe that You redeemed, Mount Zion, where You dwell (Ps 74:2).

Whether it is Melchizedek or Abram who receives the tithe, the gesture has come in this text to represent the blessing of the priest-king to both Abram and God, loyalty to the "God Most High," creator and redeemer, and the perpetuation of the reciprocal alliance between Melchizedek and Abram.

\section{$9 \quad$ Verse 20}

$$
\text { וברוך אל עליון אשר-מגן צריך בידך ויתן-לו מעשר מכל: }
$$

"And blessed be God Most High, Who has delivered your foes into your hand." And Abram gave him a tenth of everything (Gen 14:20).

Brueggemann suggests in relation to the shift between the god of Melchizedek "creator of heaven and earth" and the personal God of Abram in the poem represented by vv. 19-20 as reflecting:

the history of a struggle by which the God of Israel usurped the functions of other gods and came to be confessed as the High God of Canaan and all else. ${ }^{66}$

Brueggemann makes explicit the earlier suggestion that although these three verses referring to the relationship between Abram and Melchizedek appear to be an insertion, they are in fact the climax of the chapter. The climactic realization is that Abram has, through his routing of the kings of the "four quarters," established the pre-eminence of his God in Palestine, in the world, and in history.

Melchizedek blesses God in the same terms in which he blessed Abram. This text is establishing an elaborate hierarchy, in terms of which ultimately Abram ranks only below his "Most High God." The implications of Abram's relationship with his God are significant for the entire known world:

66 Brueggemann, Genesis, 136; also, Habel, "Yahweh," 336-37. 
The effect of the interpolation is to make not Abraham but El 'Elyon, i.e., Yahweh, appear as the ultimate source of Abraham's accomplishments. ${ }^{67}$

The translation of מגן here, is "deliver, give." The cognate word in Akkadian is "magannu," the word for "gift, without payment." 68 In the same verse, נתן is used in respect of "giving," echoing the implications raised by מגן here. The verbs are used in parallelism in a number of biblical passages e.g.:

\section{תתן לראשך לוית-חן עטרת תפארת תמגנך:}

She will adorn your head with a graceful wreath; Crown you with a glorious diadem (Prov 4:9). ${ }^{69}$

מגן also means "shield" in the first verse of the next chapter:

אחר הדברים האלה היה דבר-יהוה אל-אברם במחזה לאמר אל-תירא אברם אנכי מגן לך שכרך הרבה מאד:

Some time later, the word of the LORD came to Abram in a vision. He said, "Fear not, Abram, I am a shield to you; Your reward shall be very great" (Gen 15:1).

The implication is that Abram was the donor in ch. 14 and in ch. 15 he is to receive his reward - "payment." This "payment" would seem, in God's terms to be progressive, in that it is the promise of the land that is being fulfilled here in ch. 14:

... the four kings had conquered all regions of Transjordan, Edom and the Negeb, then they victoriously crossed all Canaan from south to north, and Abraham overtook them near Dan (the traditional northern border of Israel), defeated them, and pursued them beyond Damascus: therefore Abraham inherited all fruits of their conquests, and everything from Elath to Dan (even including Damascus and South Syria, claimed by the Israelites as part of "Greater Canaan") legally belongs to Abraham and his descendants. ${ }^{70}$

\section{CONCLUSION}

My suggestion is that the writer is invoking the image of sovereign hegemony of "the four quarters" in order to correlate Abram's defeat of four invader kings with his access to the Promised Land and with the accession of the God of Israel to God of the known world. The image with its metaphorical implications predates the patriarchal period and was still well established by the time of

67 Gammie, "Loci," 385.

68 HALOT, 545.

69 Also, Hos 11:8.

70 Astour, "Cosmic Symbolism,” 73-74. 
Daniel and the apocalyptic period. The use of "the four quarters" as a metaphor for hegemony imposes a structure on the episode. The four invader kings are first defeated by a foursome comprising Abram and his allies and then compared and opposed to a newly instated hierarchy of which the king of Sodom ranks lowest followed by Melchizedek both king and priest, then Abram who is neither and then God. This foursome accedes to all the land that was recovered from the invaders establishing Abram's claim to the Promised Land God's hegemony over the known world.

Abram is the only character in the text who is not a king, and we are reminded that the prophets inveighed against kingship on the grounds that it represented the people's claim to rule over themselves. In the same way, the word מלחמה of v. 2 where it is a function of the relations between the two blocs of kings becomes לחם in the hands of Melchizedek. It has been stripped of the connotations that it has derived from the warlike, aggrandizing and irreligious connotations in the first two verses, and becomes a function of the sacrament between Abram and Melchizedek, king of שלם - " שחברון, Leace." Abram, the invader kings, and the kings of the valley, are initially related by חבר שבר. The two sets of kings are joined in חברו at the Vale of Siddim. Necessarily Abram turns to his allies בעלי ברית, invoking the covenant with God as he does so. Most significant is the repetition of the word עמק augmented by שוה. The kings are all associated with the valleys and plains and even with "level" plains. In contrast, both Melchizedek and Abram in different respects are related to the God "Most High" - אל עליון. The king of "righteousness" and "peace," brings לחם in the name of his god "Most High," which is received by Abram. The tithe that the one gives the other, establishes a new hierarchy, in which the cities of the plain are subordinate to the kings of the heights and their God. Abram having expelled the invaders, establishes the hegemony of his God over the region. The tithe establishes his subordination to the priest of his אל עליון, imposing a hierarchy in which the priests serve God and Abram is subordinate to the priesthood. In these terms he establishes God's hegemony over the land. The result of these references is to represent the domain historical, geographical and literary, of the "Most High God" of Abram.

\section{WORKS CITED}

Astour, Michael C. "Political and Cosmic Symbolism in Genesis 14 and its Babylonian Sources." Pages 65-112 in Biblical Motifs: Origins and Transformations. Edited by Alexander Altmann. Cambridge: Harvard University Press, 1966. https://doi.org/10.4159/harvard.9780674729605.c4

Berlin, Adele. The Dynamics of Biblical Parallelism. 2nd ed. Bloomington: Indiana University Press, 1985.

Brown, Francis, Samuel R. Driver, and Charles A Briggs. The Brown-Driver-Briggs

Hebrew and English Lexicon. 12th ed. Massachusetts: Hendrickson Publishers Inc., 1906.

Brueggemann, Walter. Genesis. IBC. Atlanta: John Knox Press, 1982. 
Cogan, Mordechai. The Raging Torrent. 1st ed. Jerusalem: CARTA, 2008.

Daryaee, Touraj. Sahrestaniha i Eransahr: A Middle Persian Text on Late Antique Geography Epic and History. Costa Mesa, CA: Mazda Publishers Inc., 2002.

Deken, Alice. "Does Prophecy Cause History? Jeremiah 36 - A Scroll Ablaze." OTE 30/3 (2017): 630-52.

Emerton, John A. "The Riddle of Genesis XIV." VT 21/4 (1971): 403-39.

Even-Shoshan, Abraham. A New Concordance of the Bible. 7th ed. Israel: The New Book, 2000.

Frayne, Douglas. The Royal Inscriptions of Mesopotamia. Sargonic and Gutian Periods. Toronto: University of Toronto Press, 1993.

Gammie, John G. "Loci of the Melchizedek Tradition of Genesis 14:18-20." JBL 90/4 (1971): 385-96. https://doi.org/10.2307/3263610

Habel, Norman C. "Yahweh, Maker of Heaven and Earth: A Study in Tradition Criticism." JBL 91/3 (1972): 321-37. https://doi.org/10.2307/3263165

Horowitz, Wayne. Mesopotamian Cosmic Geography. Winona Lake: Eisenbrauns, 2011.

Jewish Publication Society. JPS Hebrew-English Tanakh. 2nd ed. Philadelphia: The Jewish Publication Society, 1999.

Koehler, Ludwig, Walter Baumgartner, and Jakob Stamm. Translated by Mervyn E. J. Richardson. The Hebrew and Aramaic Lexicon of the Old Testament. Study ed. Leiden: Brill, 2001.

Na'aman, Nadav. "Abraham's Victory over the Kings of the Four Quadrants in Light of Darius I's Bisitun Inscription." Tel Aviv 42 (2015): 72-88.

Potts, Daniel T. "Once More on 'the General Who Is Above the Four Generals' and his Congeners." NABU 3 (2007): note 51.

Sarna, Nahum M. Genesis. JPSTC. Philadelphia: The Jewish Publication Society, 1989.

Skinner, John. A Critical and Exegetical Commentary on Genesis. ICC. New York: Charles Scribner's Sons, 1910.

Smith, R. H. "Abram and Melchizedek (Gen 14.18-20)." ZAW 77 (1965): 129-52.

Speiser, Ephraim A. Genesis. AYB. New Haven: Doubleday, 1964.

Swain, Joseph W. "The Theory of the Four Monarchies Opposition History Under the Roman Empire." CP 35/1 (1940): 1-21.

Tadmor, Hayim and Shigeo Yamad. The Royal Inscriptions of Tiglath-Pileser III (744-727 BC), and Shalmaneser V (726-722 BC), Kings of Assyria. Winona Lake, IN: Eisenbrauns, 2011.

Waltke, Bruce K. and Cathi J. Fredricks. Genesis: A Commentary. Grand Rapids: Zondervan, 2001.

Yoffee, Norman. "Political Economy in Early Mesopotamian States." ARA 24 (1995): 281-311. https://doi.org/10.1146/annurev.an.24.100195.001433

Alice Deken, Research Fellow, Department of Old and New Testament Studies, University of the Free State, South Africa. Paul van Ostaijenlaan 18, 1187VC Amstelveen, The Netherlands. E-mail: alice.deken@gmail.com. ORCID ID: https://orcid.org/0000-0003-3770-8443 